\title{
Relationship Between Profitability, Investment Decisions On Firm Value: A Study Of Listed Banks In Indonesia
}

\author{
Chalimatuz Sa'diyah
}

Economics and Business Faculty, Muhammadiyah University of Malang, Indonesia

*Corresponding author. Email: chalimatuzsadiyah@umm.ac.id

The purpose of this study is to determine the effect of profitability, capital structure, and investment decisions on firm value in the property, real estate and building construction sectors listed on the Indonesia Stock Exchange for the 2015-2019 period. The population in this study were 83 companies. The sampling technique in this study was purposive sampling and produced a sample of 30 companies. The data analysis technique in this study uses multiple linear regression, while the analysis tool used is SPSS 25. This research hypothesis states that profitability has a positive and significant effect on firm value, capital structure has a positive and significant effect on firm value, investment decisions have a positive and significant effect. to company value.

Keywords: Profitability, Capital Structure, Investment Decisions, Company Value

OPEN ACCESS

ISSN 2528-4649 (online) ISSN 2338-4409 (print)

Reviewedby: Zarah Puspitaningtyas, Irwan Moridu

${ }^{*}$ Correspondence: Chalimatuz Sa'diyah chalimatuzsadiyah@umm.ac.id

Received:May 22, 2021

Accepted: August 28, 2021 Published: September 20, 2021 JBMP: Jurnal Bisnis, Manajemen dan Perbankan. Vol: $7 /$ No. 2 doi: 10.21070/jbmp.v7vi2.1469 


\section{INTRODUCTION}

Firm value is one of the parameters to determine the company's performance. Companies that have high productivity certainly have good corporate values. The objects used in this study are property, real estate and building construction sector companies listed on the IDX during the 2016-2019 period. Infrastructure development in Indonesia is currently starting to develop, as evidenced by various developments carried out by the government. The property, real estate and building construction sectors benefit greatly from the quality of infrastructure in Indonesia. Good infrastructure will stimulate investors to invest in this sector, because good infrastructure is expected to be able to make property, real estate and building construction acceptable to the community.

The safest choice sectors for investors to invest in are the property, real estate and building construction sectors. The bright prospects owned by the property, real estate and building construction sectors are the reason investors choose to invest in this sector, and people consider property as part of their primary needs that must be met. The times have made property prices also increase (Yanti and Abundanti 2019). This, of course, is supported by data on the commercial property price index as well as the commercial property demand index which is shown in the chart below:

[Figure 1 about here.]

Based on the graph above, it can be concluded that from 2017 to 2019 , both the commercial property price index and the commercial property demand index continued to increase, this shows that the property sector is a sector that is very attractive to people to invest. In 2020, both charts showed a significant decline, the decline in the commercial property price index and the commercial property demand index was caused by the Covid-19 pandemic. The current Covid-19 of course has an impact on weakening the economy of the people in Indonesia, of causes a decrease in public interest in investing, one of which is in the property, real estate and building construction sectors.

The decline in public interest in investing will of course has an impact on the share price of the company. The declining share price of course will also have an impact on the decreasing company value, and vice versa. (Oktarina 2018) states that the price a buyer can pay if the company is sold is the definition of company value, while according to (Khasawneh and Staytieh 2017) share prices can reflect the value of a company. A high stock price indicates that the higher the value of a company. The tool that can be used to measure company value is Price Book Value (PBV), which is a comparison between the market value of stocks and the book value of stocks.

The first factor affecting firm value is profitability. Profitability according to (Sudiani and Wiksuana 2018) is a measure of the effectiveness of a company and is used to measure the company's ability to obtain profits. Profitability ratios that better illustrate the ability of the company's high profitability, this of course will affect the selling price of shares. The high selling price of shares will indicate the higher the value of the company (Hamidah, Hartini, and Mardiyati 2015). The profitability ratio used in this study is Return On Assets (ROA). ROA is used in this study because ROA can show the operational efficiency of a company so that it shows the company's performance.

The second factor that affects firm value is the capital structure. Capital structure is a balanced form of corporate finance which is described by capital owned by debt (liabilities) and equity (shareholders equity) (Ikpesu and Eboiyehi 2018). The optimal capital structure in a company is a combination of debt and equity (external sources) that maximizes the company's share price (Dietsch and Khemiri 2018).

Apart from the factors above, some researchers believe that investment decisions can increase firm value. Conducting investment activities is the most difficult decision for company management because it will affect the value of the company (Vranakis and Chatzoglou 2011). Investment decisions affect the firm value if the company shows that some investments will get a surplus if the company makes the right investment decisions. The company invests to get profit in the future. Investment decisions can be measured by the Price to Earning Ratio (PER) (Ayem and Nugroho 2016).

PER is widely used by capital market analysts to see the performance of a company as expected by investors. Research by (Ayem and Nugroho 2016) shows that investment policy has a positive effect on firm value. This shows that the greater the funds invested, the greater the firm value. However, (Fauziah 2018) show different results, namely that investment decisions have no effect on firm value, because the level of investment decisions that use PER as a measuring tool cannot affect the size of the company value.

Based on the phenomena and previous research, the researcher wants to make a study like a title described above. The purpose of this study was to determine the effect partially and simultaneously between the variables of profitability, capital structure, and investment decisions on firm value in the property, real estate and building construction sectors.

\section{LITERATURE REVIEW}

A financial manager has a goal to be achieved in a company, namely maximizing the prosperity of shareholders through increasing company value. Firm value is the company's performance as reflected by the stock price which is formed by the demand and supply of the capital market, which reflects the public's assessment of the company's performance. In this study, the measurement of firm value uses the Price Book Value (PBV) measurement. Because the PBV ratio shows the level of the company's ability to create value relative to the amount of invested capital (Nurhayati 2013). 
Every company wants to show the ability to generate profits. Profitability is a description of financial performance in managing a company that shows the company's success in generating profits (Brigham and Houston 2012). Profitability is the company's ability to seek profit. The measurement of profitability in this study uses the Return on Equity (ROE) ratio. The higher the ROE, the higher the rate of return on investment made by shareholders in a company.

Increased profitability in the company can create value for the company because when profitability is high it will show the efficiency of the company. so that the investors will invest in the company. This is supported by research (Sucuahi and Cambarihan 2016) which states that profitability has a positive and significant effect on firm value. H1: Profitability has a positive and significant effect on firm value.

Financial management must be wise in making capital structure decisions. Errors in determining the capital structure have a broad impact, especially if the company is too large in using debt, then the fixed burden that must be borne by the company is getting bigger too. According to (Fahmi 2011), the definition of capital structure is a description of the form of the company's financial proportion, namely the capital owned by long-term liabilities and shareholder's equity which is the source of a company's financing.

The capital structure which is proxied by Debt To Equity Ratio (DER) if properly composed and used optimally can provide high value for company value. According to the trade off theory, debt is used optimally and as long as it has not exceeded the optimal limit of use of debt, it can increase company value. According to research (Situmeang and Wiagustini 2018) and (Pratiwi, Yudiaatmaja, and Suwendra 2016) state that capital structure (DER) has a positive and significant effect on firm value. $\mathrm{H} 2$ : Capital structure has a positive and significant effect on firm value.

Investment decisions are one of the functions of financial management regarding the allocation of funds, both funds sourced from within and from outside the company in various forms of investment decisions to obtain greater profits than the cost of funds in the future (Kurniasih and Ruzikna 2017). An investment decision is a long-term investment decision that concerns the expectation of the return on profits obtained by shareholders. The company is expected to grow by increasing high growth, meaning that companies that have good prospects usually have a high price earning ratio. On the other hand, companies that are expected to have low growth will have a low price earning ratio (Hanafi and Halim 2014).

The investment decision is the most important decision of the other decisions, in terms of increasing company value. The prospect of growth is an expectation desired by the company (internal parties) and investors and creditors (external parties). This growth prospect provides a positive signal for a company in the future. Because the greater the investment invested by investors, the higher the level of investor confidence in the company. Research (Ayem and
Nugroho 2016) show that investment policy has a positive effect on firm value. H3: Investment decisions have a positive effect on firm value.

Based on the description above, the conceptual framework is described as follows:

\section{[Figure 2 about here.]}

\section{METHOD (FOR RESEARCH ARTICLE)}

Research design. This research uses causal associative research because it examines the effect of profitability, capital structure and investment decisions on firm value property, real estate and building construction companies listed on the Indonesia Stock Exchange (IDX) for the period 2015 to 2019. Sources of data used in this study constitute secondary data accessible at www.idx.go.id. The type of research used in this study according to the level of explanation is a quantitative description. This research period will be analyzed for 5 periods, namely from 20152019.

The population of this study is the property, real estate and building construction sector companies listed on the IDX, amounting to 83 companies. The samples in this study were 30 companies. The sample selection used purposive sampling method. Purposive sampling method, namely samples taken based on certain criteria to obtain samples that match the research objectives. The criteria used in this study are shown in table 1:

[Table 1 about here.]

Company value is the selling value of a company as an operating business. The existence of an excess selling value above the liquidation value is the value of the management organization that runs the company (Sartono 2011). Firm value can be measured by Price Book Value (PBV), according to (Weston and Copeland 2011). PBV can be formulated as follows:

$$
P B V=\frac{(\text { Harga per lembar Saham) }}{\text { Nilai Buku Saham }}
$$

Profitability is the ratio of the company's ability to seek profit. This profitability is calculated using Return on Equity (ROE), to measure the level of return on investment made by the owner of a company's shareholders. The following is the ROE formula according to (Kasmir 2014) as follows:

$$
R O E=\frac{(\text { Laba Bersih Setelah Pajak })}{(\text { Ekuitas Pemegang Saham })}
$$

The capital structure is a permanent balance of short-term debt long-term preferred stock and common stock. Capital structure is measured by the Debt Equity Ratio (DER). DER is a ratio to measure the balance between the liabilities 
owned by the company and its capital. According to (Kasmir 2014) DER can be formulated as follows:

$$
D E R=\frac{(\text { Total Utang })}{(\text { Total Ekuitas })}
$$

Investment decisions are financial decisions about assets that must be purchased by a company (Sundana 2011). One of the ratios used to determine investment decisions is the Price to Earning Ratio (PER). PER measures how much the comparison between the company's share price and the profit that will be obtained by shareholders (Sundana 2011) formulated PER as follows:

$$
P E R=\frac{(\text { Harga Saham })}{(\text { Laba Per Lembar Saham })}
$$

The data collection method used in this research is the documentation method, which is looking for data on variable matters in the form of notes or transcripts, books, newspapers, magazines, meeting minutes, and so on. This documentation method is usually through company financial reports, official websites, journals, books, etc. The data analysis technique used in this study is multiple linear regression and to process the data the tool used is SPSS 25.

\section{RESULTS AND DISCUSSION}

[Table 2 about here.]

The results of descriptive statistical testing in the table above show that the lowest value of the profitability variable is 0.04 and the highest value is 23.48. The distribution of profitability data is said to be good because the average value (mean) is greater than the standard deviation, namely $8.8525>5.74244$. The results of descriptive statistical testing in the table above show that the lowest value of the capital structure variable is 0.02 and the highest value is 5.86 . The distribution of capital structure data is said to be good because the average value (mean) is greater than the standard deviation, namely $1.1075>0.96863$.

The results of descriptive statistical testing in the table above show that the lowest value of the investment decision variable is 0.76 and the highest value is 1046.10. The distribution of profitability data is said to be not good because the average value (mean) is smaller than the standard deviation, namely $30.5473>91.85608$. The results of descriptive statistical testing in the table above can be seen that the lowest value of the firm value variable is 0.15 and the highest value is 6.92. The distribution of capital structure data is said to be good because the average value (mean) is greater than the standard deviation, namely 1.1837 $<0.95023$.
Based on the Kolmogorov-Smirnov test, a significance value exceeding 0.05 was obtained, which is 0.076 . This proves that the data in this study are normally distributed.

[Table 4 about here.]

Tests that have been carried out in this study indicate that the Tolerance value is more than 0.1 , while the VIF value is not more than 10 . This means that the data in this study do not experience multicollinearity symptoms.

[Figure 3 about here.]

The scatterplot graph in this study shows that there is no symptom of heteroscedasticity or it can be said that the graph is homoscedasticity. This is because the graph above shows that the dots are scattered randomly and do not form a certain pattern, the graph above also shows that the dots are spread above and below point 0 .

[Table 5 about here.]

Based on the test results, the data used in this study had no autocorrelation symptoms. This is because the results of Durbin Watson's calculations have met the criteria for no autocorrelation. The criteria so that autocorrelation does not occur is $\mathrm{dU}<\mathrm{DW}<4-\mathrm{dU}$, this is similar to Durbin Watson's results in the table above, namely $1.7741<1.958<2.2259$.

\section{[Table 6 about here.]}

Multiple linear regression is used to analyze the effect of profitability, capital structure, and investment decisions on firm disclosure value with the following equation: $\mathrm{Y}=1.593$ $+0.411 \mathrm{X} 1+0.409 \mathrm{X} 2+0.280 \mathrm{X} 3$.

Based on the table, the $\mathrm{t}$-count value is $5,567>1,65508$ and a significant value of 0,000 . The significance value of profitability which is proxied by a ROA that is smaller than the expected significance (0.05) indicates that the profitability variable has a positive and significant effect on the value of the property, real estate and building construction companies listed on the Indonesia Stock Exchange for the period 2015-2019 so that H1 accepted.

Based on the table, the $\mathrm{t}$-count value is $7,942>1.65508$ and a significant value is 0.000 . The significance value of capital structure which is proxied by a DER which is smaller than the expected significance (0.05) indicates that the capital structure variable has a positive and significant effect on the value of the property, real estate and building construction companies listed on the Indonesia Stock Exchange for the 2015-2019 period, so that H2 is accepted. 
Based on the table, the t-count value is 3.191> 1.65508 and a significant value is 0.002 . The significance value of investment decisions which is proxied by a PER that is smaller than the expected significance $(0.05)$ indicates that the investment decision variable has a positive and significant effect on the value of the property, real estate and building construction companies listed on the Indonesia Stock Exchange for the 2015-2019 period, so that H3 is accepted.

[Table 7 about here.]

Based on the table above, it can be proven that the value of f-count> f-table is 48.875> 2.4300 and a significance value of less than 0.05 , namely the significant value in this study $0.000<0.05$, it can be concluded that profitability, capital structure, investment decisions simultaneously influence firm value.

[Table 8 about here.]

From the test results above, it can be concluded that the value of Adjusted $\mathrm{R}$ Square has a value of 0.925 or equivalent to $93 \%$. This proves that the variables of profitability, capital structure and investment decisions can explain the variable firm value by $93 \%$, while the remaining $7 \%$ is explained by other variables outside the variables calculated here.

Research proves that profitability (ROE) has a positive effect on firm value (PBV). This means that the higher the level of profitability of a company in the property, real estate and building construction sector, the company value will increase, and vice versa. If you look at the conditions during the 5 years 2015-2019 the property, real estate and building construction sectors experienced growth so that the generated profits increased but only a few percentages. The results of this study support and are in line with the results of research conducted by (Sudiani and Wiksuana 2018), (Lubis, Sinaga, and Sasongko 2017), (Pratiwi et al. 2016) and (Al Daas, Ahmad, and Mohammad 2020) found that profitability (ROE) has a positive effect on firm value.

The Effect of Capital Structure (DER) on Firm Value (PBV). Hypothesis 2 (H2) is accepted, it is proven that the capital structure (DER) has a positive effect on firm value (PBV). This means that the company uses debt to signal a more reliable one for investors and this is one of the company's intentions of being confident about the company's prospects. The use of debt gives a positive sign of something companies that can make investors appreciate the value of shares greater than the value recorded on the company's balance sheet. The results of this study support and are in line with several studies from (Pratiwi et al. 2016), (Hirdinis 2019), (Pangulu 2014) and (Diannisa, Lukytawati, and Koes 2019) state that capital structure (DER) has a positive effect on firm value. However, this research is not in line with research from (Ayem and Nugroho 2016), (Riana and
Iskandar 2017) and (Komarudin and Affandi 2019) which prove that capital structure (DER) does not affect firm value. In fact (Dang et al. 2019) proved that the structure of the model has a negative effect on firm value.

The Effect of Investment Decisions (PER) on Firm Value (PBV). Hypothesis 3 is accepted, based on the results of research which found that investment decisions (PER) have a positive effect on firm value (PBV). This can be seen from the company's growth prospects which provide a positive signal for a company in the future. The bigger the investment invested by investors, the more high level of investor confidence in the company. A high PER value also indicates a good company investment and good company prospects so that many investors are interested in investing in property, real estate and building construction companies. The results of this study support and are in line with research from (Kurniasih and Ruzikna 2017) which states that investment decisions (PER) have a positive effect on firm value (PBV). However, this research is not in line with research from (Fauziah 2018) which states that investment decisions (PER) do not affect firm value (PBV).

\section{CONCLUSIONS}

The net profit generated by property, real estate and building construction companies during the 2015-2019 period has increased on average, so it has a direct effect on company value through the company's stock price. In this case, it shows that the resulting ROE will provide high profitability so that the rate of return on capital is high on investments made by stock owners in a company. The higher the profitability of the company, the higher the level of prosperity a company provides to attract investors.

The property sector, real estate and building construction during the 2015-2019 period dare to increase their debt because this is one of the strategies of shareholders to optimize the capital structure of company value. Shareholders are quite confident about the company's prospects so that companies with debt can be seen as having good company prospects in the eyes of investors.

The property, real estate and building construction sectors during the 2015-2019 period experienced good growth in share prices in a market. This provides an opportunity for potential investors to make large investments, thereby providing the creation of maximum corporate value. Shareholders are quite confident about the company's prospects so that companies with debt can be seen as having good company prospects in the eyes of investors.

\section{ACKNOWLEDGEMENT}

The author would like to thank the Faculty of Economics and Business, University of Muhammadiyah Malang, which has helped with funding this research. The author also expresses gratitude to my family who have motivated me to continue working in the profession that I am involved in. 


\section{REFERENCES}

Ayem, S., and R. Nugroho. 2016. "Effect of Profitability, Capital Structure, Dividend Policy on Firm Value (Case Study of Manufacturing Companies That Have Go Public on the IDX 2010-2014.” Journal of Accounting 4(1):12-25.

Brigham, and Houston. 2012. Fundamentals of Financial Management. Fifth Edit. Jakarta: Salemba Empat.

Al Daas, A., M. U. Ahmad, and S. J. Mohammad. 2020. "The Dynamics between Dividends, Financing and Investments: Evidence from Jordanian Companies.” International Journal of Financial Research 11(4):231-40.

Dang, HN, VTT Vu, XT Ngo, and HTV Hoang. 2019. "Study the Impact of Growth, Firm Size, Capital Structure, and Profitability on Enterprise Value: Evidence of Enterprises in Vietnam." The Journal of Corporate Accounting \& Finance 30(1):144-60.

Diannisa, S. R. Y., A. Lukytawati, and P. Koes. 2019. "Impact of Capital Structure and Firm Financial Performance on Firm Value: Evidence of Agribusiness Firms in Indonesia Stock Exchange.” Russian Journal of Agricultural and SocioEconomic Sciences 85(1):445-51.

Dietsch, D., and R. Khemiri. 2018. "Impact of the Use of Knowledge Obtained through Informal Exchanges on the Performance of Innovation Projects: For the Enrichment of Inbound Open Innovation Practices." International Journal of Innovation Management 22(6).

Fahmi, Irham. 2011. Manajemen Resiko. Bandung: Alfabeta.

Fauziah, A. 2018. "The Effect of Investment Decisions, Funding Decisions, Dividend Policy, and Profitability on Firm Value (Studies on Industrial and Chemical Companies Listed on the IDX for the Period 2012-2016." Journal of Management Science 6(3):112-25.

Hamidah, Hamidah, Hartini Hartini, and Umi Mardiyati. 2015. "Pengaruh Inflasi, Suku Bunga Bi,Profitabilitas, Dan Risiko Finansial Terhadap Nilai Perusahaan Sektor Properti Tahun 2011-2013.” JRMSI - Jurnal Riset Manajemen Sains Indonesia 6(1):395.

Hanafi, M., and A. Halim. 2014. Financial Statement Analysis. Yogyakarta: (UPP) STIM YKPN.

Hirdinis, M. 2019. “Capital Structure and Firm Size on Firm Value Moderated by Profitability.” International Journal of Economics and Business Administration 7(1):174-91.

Ikpesu, Fredrick, and Osazemen C. Eboiyehi. 2018. "Capital Structure and Corporate Financial Distress of Manufacturing Firms in Nigeria." Journal of Accounting and Taxation 10(7):78-84.

Kasmir. 2014. Analisis Laporan Keuangan. Edisi Pert. Jakarta: PT. Rajagrafindo Persada.

Khasawneh, Ahmad Y., and Kareem S. Staytieh. 2017. "Impact of Foreign Ownership on Capital Structure and Firm Value in Emerging Market: Case of Amman Stock Exchange Listed Firms.” Afro-Asian Journal of Finance and Accounting 7(1):3564.

Komarudin, Mamay, and Naufal Affandi. 2019. "Firm Value, Capital Structure, Profitability, Firm Characteristic and Disposible Income As Moderator: An Empirical Investigation of Retail Firms in Indonesia.” Inovbiz: Jurnal Inovasi Bisnis 7(1):79.

Kurniasih, B., and Ruzikna. 2017. "The Influence of Capital Structure and Investment Decisions on Firm Value in the Food and Beverage Industry Listed on the IDX.” FISIP Journal 4(2):1-14.

Lubis, I., BM Sinaga, and H. Sasongko. 2017. "Effect of Profitability, Capital Structure, and Liquidity on Firm Value." Journal of Business and Management Applications 3(3):458-65.

Nurhayati, M. 2013. "Profitability, Liquidity and Company Size Impact on Dividend Policy and Company Value in the Non-Service Sector.” Journal of Finance and Business 5(2):144-53.

Oktarina, Dian. 2018. "The Analysis of Firm Value in Indonesia Property and Real Estate Companies." International Journal of Research Science \& Management 5(9):85-92.

Pangulu, A. L. 2014. "The Effect of Profitability, Growth Opportunity, and Capital Structure on Firm Value (Studies on Banking Companies Listed on the IDX for the Period 2011-2013).” Journal of Social Sciences 4(2):1-12. 
Pratiwi, NPY, F. Yudiaatmaja, and IW Suwendra. 2016. "The Effect of Capital Structure and Firm Size on Firm Value." Management Journal 4:1-9.

Riana, and D. Iskandar. 2017. "The Influence of Company Size, Corporate Governance, and Capital Structure on Firm Value (Empirical Study of Mining Companies Listed on the Indonesia Stock Exchange Period 2011 - 2014)." Profita 10(3):409-25.

Sartono, A. 2011. Financial Management Theory and Applications. Yogyakarta: BPFE UGM.

Situmeang, Yohana Mutiara Lambok, and Ni Luh Putu Wiagustini. 2018. "Pengaruh Struktur Modal Terhadap Nilai Perusahaan Dengan Kebijakan Herging Sebagai Mediasi Pada Perusahaan BUMN Go-Public." E-Jurnal Manajemen Unud 7(3):1368-96.

Sucuahi, William, and Jay Mark Cambarihan. 2016. "Influence of Profitability to the Firm Value of Diversified Companies in the Philippines." Accounting and Finance Research 5(2).

Sudiani, N. K. A., and I. G. B. Wiksuana. 2018. "Capital Structure, Investment Opportunity Set, Dividend Policy and Profitability as a Firm Value Determinants." Russian Journal of Agricultural and Socio-Economic Sciences 9(September):3751.

Sundana, I. M. 2011. Corporate Financial Management. Jakarta: Erlangga.

Vranakis, Stergios, and Prodromos Chatzoglou. 2011. "A Conceptual Model for Machinery \& Equipment Investment Decisions.” International Journal of Business and Management 7(1).

Weston, JF, and Copeland. 2011. Fundamentals of Financial Management. 2nd ed. Jakarta: Erlangga.

Yanti, Putu Diah Melinda, and Nyoman Abundanti. 2019. "Pengaruh Profitabilitas, Leverage Dan Kebijakan Dividen Terhadap Nilai Perusahaan Properti, Real Estate Dan Konstruksi Bangunan.” E-Jurnal Manajemen Universitas Udayana Vol. 8, No(ISSN : 2302-8912):5632-51.

Conflict of Interest Statement: The authors declare that the research was conducted in the absence of any commercial or financial relationships that could be construed as a potential conflict of interest.

Copyright (C) tahun terbit nama belakang and nama belakang. This is an openaccess article distributed under the terms of the Creative Commons Attribution License (CC BY). The use, distribution or reproduction in other forums is permitted, provided the original author(s) and the copyright owner(s) are credited and that the original publi-cation in this journal is cited, in accordance with accepted academic practice. No use, distribution or reproduction is permitted which does not comply with these terms. 


\section{LIST OF FIGURES}

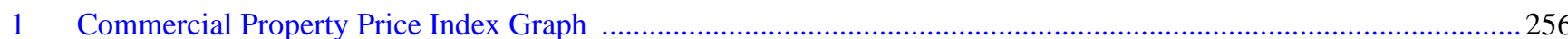

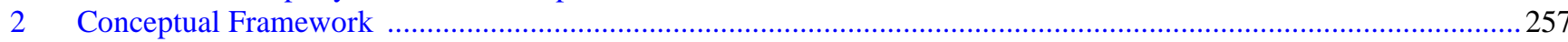

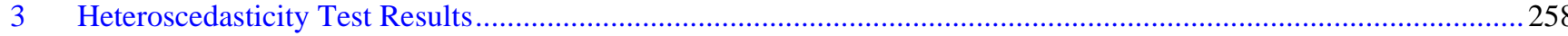




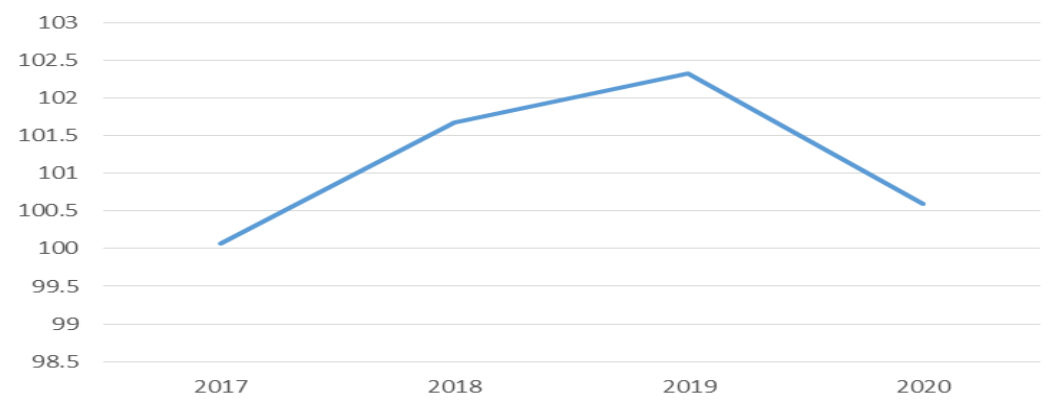

Figure 1 | Commercial Property Price Index Graph 


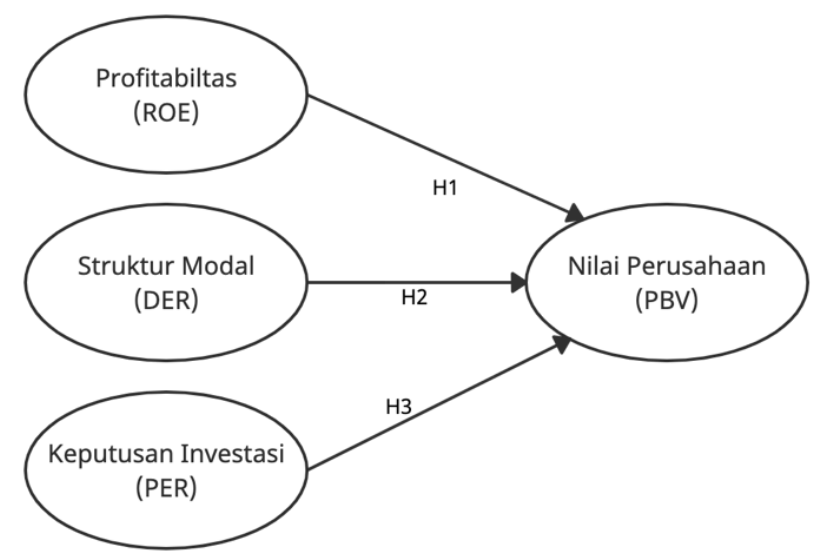

Figure 2 | Conceptual Framework 


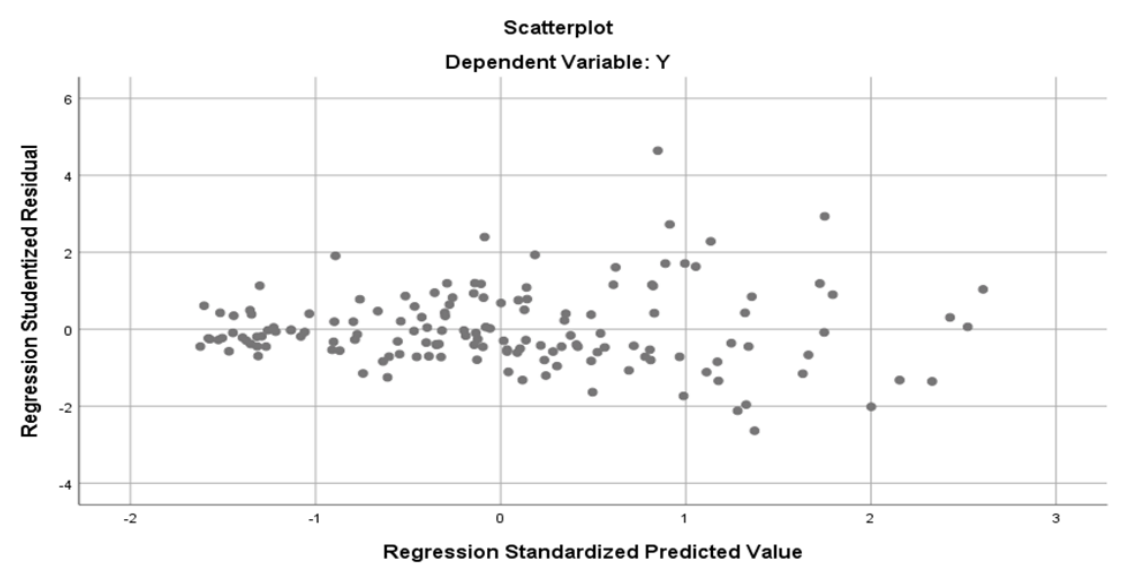

Figure 3 | Heteroscedasticity Test Results 


\section{LIST OF TABLES}

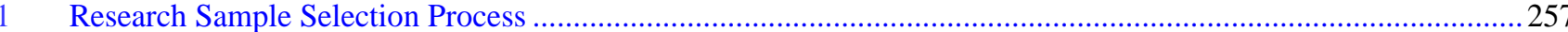

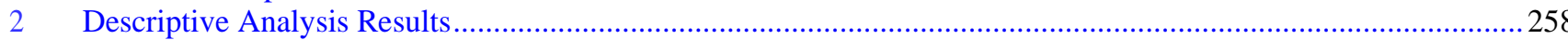

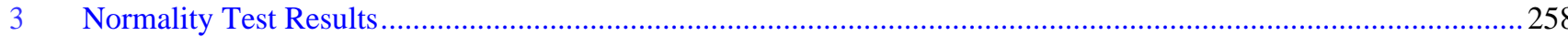

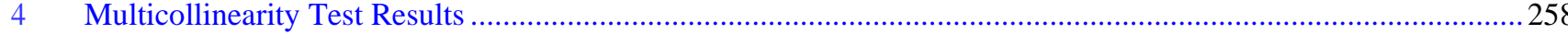

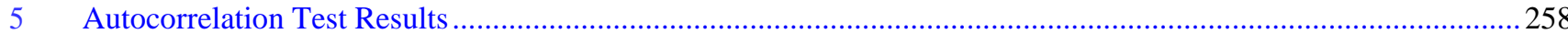

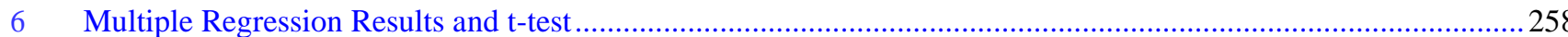

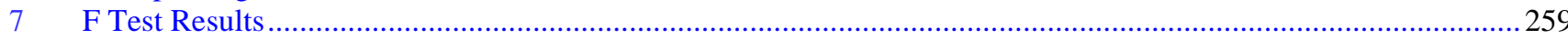

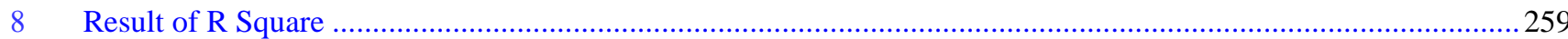


TABLE 1 | Research Sample Selection Process

\begin{tabular}{clc}
\hline No. & \multicolumn{1}{c}{ Criteria } & Amount \\
\hline 1 & Number of Property, Real Estate and Building Construction Companies Listed on the IDX & 83 \\
2 & The property, Real Estate and Building Construction Companies with Minus ROE & -20 \\
3 & The property, Real Estate and Building Construction Companies that have been Delisted & -2 \\
4 & The property, Real Estate and Building Construction Companies That Do Not Have & -20 \\
& $\begin{array}{l}\text { Complete Data on Financial Statements } \\
5\end{array}$ & $\begin{array}{l}\text { Property, Realestate and Building Construction Companies that Do Not Report Financial } \\
\text { Statements }\end{array}$ \\
\hline & $\quad$ Total Sample of Property, Real Estate and Building Construction Companies & -11 \\
\hline & Total Sample (30 x 5 Years) & 30 \\
\hline
\end{tabular}


TABLE 2 | Descriptive Analysis Results

\begin{tabular}{lcrrrr}
\hline \multicolumn{5}{c}{ Descriptive Statistics } \\
\hline ROE & $\mathrm{N}$ & Minimum & Maximum & \multicolumn{1}{c}{ Mean } & Std. Deviation \\
DER & 150 & .04 & 23.48 & 8.8525 & 5,74224 \\
PER & 150 & .02 & 5.86 & 1.1075 & .96863 \\
PBV & 150 & .76 & 1046.10 & 30,5473 & 91.85608 \\
Valid N (listwise) & 150 & .15 & 6.92 & 1.1837 & .95023 \\
\hline
\end{tabular}

Source: Results of the analysis of SPSS 25, 2021 
TABLE 3 | Normality Test Results

\begin{tabular}{llr}
\hline \multicolumn{2}{c}{ One-Sample Kolmogorov-Smirnov Test } \\
\hline $\mathrm{N}$ & & Unstandardized Residual \\
Normal Parameters, b & Mean & 150 \\
& Std. Deviation & -.5350182 \\
Most Extreme Differences & Absolute & .62312581 \\
& Positive & .069 \\
& Negative & .069 \\
Statistical Test & & -.046 \\
Asymp. Sig. (2-tailed) & & .069 \\
\hline
\end{tabular}

Source: Results of the analysis of SPSS 25, 2021 
TABLE 4 | Multicollinearity Test Results

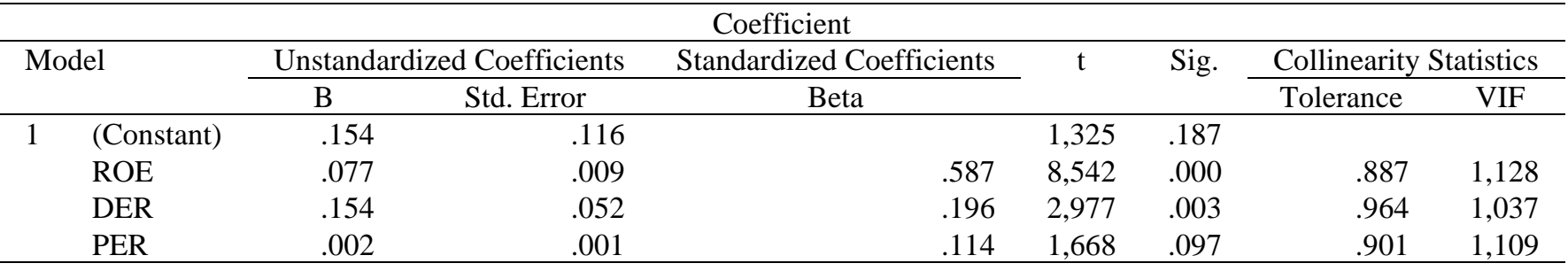

Source: Results of the analysis of SPSS 25, 2021 
TABLE 5 / Autocorrelation Test Results

\begin{tabular}{rrrrrr}
\hline \multicolumn{5}{c}{ Model Summary } \\
\hline Model & $\mathrm{R}$ & $\mathrm{R}$ Square & Adjusted R Square & Std. Error of the Estimate & Durbin-Watson \\
\hline 1 & .565 & .319 & .305 & .54547 & 1958 \\
\hline
\end{tabular}

Source: Results of the analysis of SPSS 25, 2021 
TABLE 6 / Multiple Regression Results and t-test

\begin{tabular}{|c|c|c|c|c|c|c|c|}
\hline \multicolumn{8}{|c|}{ Coefficient } \\
\hline \multirow{2}{*}{\multicolumn{2}{|c|}{ Model }} & \multicolumn{2}{|c|}{ Unstandardized Coefficients } & \multirow{2}{*}{\multicolumn{2}{|c|}{$\frac{\text { Standardized Coefficients }}{\text { Beta }}$}} & \multirow[t]{2}{*}{$\mathrm{t}$} & \multirow[t]{2}{*}{ Sig. } \\
\hline & & $\mathrm{B}$ & Std. Error & & & & \\
\hline \multirow[t]{4}{*}{1} & (Constant) & 1,593 & .345 & & & 4,614 & .000 \\
\hline & ROE & .411 & .074 & & .402 & 5,567 & .000 \\
\hline & DER & .409 & .052 & & .499 & 7,942 & .000 \\
\hline & PER & .280 & .088 & & .220 & 3,191 & .002 \\
\hline
\end{tabular}

Source: Results of the analysis of SPSS 25, 2021 
TABLE 7 / F Test Results

\begin{tabular}{ccccccc}
\hline \multicolumn{7}{c}{ ANOVA } \\
\hline & Model & Sum of Squares & df & Mean Square & F & Sig. \\
\hline \multirow{2}{*}{1} & Regression & 86,325 & 3 & 28,775 & 48,875 & .000 \\
& Residual & 85,957 & 146 & .589 & & \\
& Total & 172,281 & 149 & & & \\
\hline
\end{tabular}

Source: Results of the analysis of SPSS 25, 2021 
TABLE 8 / Result of R Square

\begin{tabular}{ccccc}
\hline \multicolumn{4}{c}{ Model Summary } \\
\hline Model & $\mathrm{R}$ & R Square & Adjusted R Square & Std. Error of the Estimate \\
\hline 1 & .963 & .927 & .925 & 4,73541 \\
\hline
\end{tabular}

Source: Results of the analysis of SPSS 25, 2021 